\title{
Two ancient mitochondrial alleles in Australian honeybees
}

\author{
S Koulianos*, RH Crozier \\ La Trobe University, Department of Genetics and Human Variation, \\ Bundoora 3083, Victoria, Australia
}

(Received 26 September 1991; accepted 29 November 1991)

\begin{abstract}
Summary - Sequence information (363 bp) was obtained following polymerase chain reaction (PCR) amplification for portions of the ATPas 6 and COIII mitochondrial genes for 8 commercial and 2 feral honeybee hives. Only 2 alleles were found; these differed by 6 base substitutions, which implies that they diverged before honeybees colonized Europe.
\end{abstract}

mitochondrial DNA (mtDNA) / genetic variation / Apis mellifera / evolution / Australia

\section{INTRODUCTION}

Allozymes, morphological markers and cuticular hydrocarbons have been considered as potential tools for the identification of honeybee strains, especially for monitoring the spread of the Africanized bees through South and Central America (Smith and Brown, 1987). The use of cuticular hydrocarbons seems promising, but their heritability is unknown (Smith and Brown, 1987).

Biometrical studies and earlier DNA studies only involved the sites where specific enzymes cleave DNA. Such information allows a characterisation of honeybee races, but generally is not sufficient to determine lineages within races. Sequencing DNA greatly increases the volume of information and therefore improves our ability to distinguish strains. We report here a method of sequencing honeybee mitochondrial DNA (based on the polymerase chain reaction, PCR) and have used the sequences obtained to characterise both Australian feral and commercial strains. Also, we are able to sequence DNA from single bees, thus allowing the development of rapid diagnostic tests for particular strains.

Once information is available in terms of the sequence of nucleotides of mtDNA from various strains, any new strain can not only be identified as such to the extent allowed by the variation actually uncovered, but its relationship along the maternal line to other strains determined.

This present research provides information on the genetic composition of feral and commercial strains by sequencing a region of the ATPase 6 and COIII mitochondrial genes.

* Correspondence and reprints 


\section{MATERIALS AND METHODS}

Bees were supplied by the University of Western Sydney, the Department of Agriculture (Western Australia) and several commercial beekeepers. Total DNA was extracted by one of 2 methods: from single bees using the method of Crozier et al (1991); and total DNA enriched with mitochondrial DNA was extracted (Crozier et al, 1989) from the thoraces of 12 bees from each hive, homogenized gently in $18 \mathrm{ml}$ of homogenizing solution.

Samples were amplified using 2 oligonucleotide primers (CGATTATCAGCAAATTTAATTTCTG and GTATACCTTGAAATGTTCTTTC. TCG) and Taq polymerase (United States Biochemical Corporation) in an (novonics ${ }^{\circledR}$ ther$\mathrm{mal}$ cycler for 40 cycles under the following conditions: denaturation at $92{ }^{\circ} \mathrm{C}$ for $1 \mathrm{~min}$, annealing at $53^{\circ} \mathrm{C}$ for $1 \mathrm{~min}$, extension at $70^{\circ} \mathrm{C}$ for 1 min. The product was purified by phenol/ chloroform extraction and the DNA precipitated with the addition of $0.1 \mathrm{vol}$ of $3 \mathrm{M} \mathrm{NaAc}$ and 2.5 vol of $95 \%$ ethanol.

Direct sequencing using the Sequenase version 2.0 sequencing kit (United States Biochemical Corp) from single-stranded PCR product was achieved by a modification of the protocol of Kessing et al (1989). Amplifications were achieved by asymmetric PCR of doublestranded product, and the latter was precipitated by adding 0.1 vol of $7 \mathrm{M} \mathrm{NH}_{4} \mathrm{Ac}$ and 2.5 vol of $95 \%$ ethanol. The DNA was pelleted, washed twice with $70 \%$ ethanol, dried and resuspended in TE buffer. The primer was annealed to the template DNA at $65^{\circ} \mathrm{C}$ and allowed to cool slowly to below $35^{\circ} \mathrm{C}$. DTT and [ $\alpha$-35 S]dATP were added and the mixture allowed to label at room temperature for $15 \mathrm{~min}$. Aliquots of this mixture were added to the 4 termination mixes, prewarmed to $37^{\circ} \mathrm{C}$ for $4 \mathrm{~min}$. The termination reaction was allowed to continue for $15 \mathrm{~min}$ at $37{ }^{\circ} \mathrm{C}$ before the stop solution was added. The completed reactions were denatured at $95{ }^{\circ} \mathrm{C}$ for $5 \mathrm{~min}$ before loading onto the gel.

Sequence information was analyzed using the Nucleic Acids Analysis System package (Genesearch, Broadbeach, Queensland) run on an Apple II computer. Divergence between alleles (d) was estimated by Kimura's (1980) method. Theoretically, the time since divergence $(t)$ can be estimated from $t=d / r$, where $r$ is the rate of divergence bet...en the 2 se- quences (Nei, 1987). Unfortunately, the rate of evolution of Apis mtDNA is unknown.

\section{RESULTS AND DISCUSSION}

Sequences were obtained from samples of 10 hives. Partial sequences were obtained for an additional 10 commercial hives (not presented here) all of which have the more popular allele.

There are 6 substitutions between sequences $\mathrm{A}$ and $\mathrm{C}$. The nucleotide diversity (Nei, 1987) is approximately equal to 0.005 .

Based on the sequence data of figure 1 , the mean divergence (and 95\% confidence limits) between the $2 \mathrm{mtDNA}$ haplotypes detected is $0.0167 \pm 7 \times 10^{-4}$. This figure is relatively large, but comparison with those for Drosophila species (Baba-Aissa and Solignac, 1984; DeSalle et al, 1986; Latorre et al, 1988; Satta et al, 1988) shows that such values are not uncommon. Given the smaller effective population size of social insects (Crozier, 1980), persistence of these alleles for so long is unexpected and may indicate their origin from more than one group of subspecies in Europe (Smith, 1991).

Two patterns of sequence divergence are evident in comparisons between species of Drosophila (DeSalle et al, 1987). The initial rate reflects the high rate of synonymous substitutions, while subsequent divergence results from the slow accumulation of replacement substitutions. The high rate of nucleotide divergence observed here $(>2 \%)$ can thus be attributed to the accumulation of synonymous substitutions. A decrease in rate is therefore expected with saturation at these sites, for Drosophila when mtDNAs differ by approximately $8 \%$.

Although no estimates of divergence times for subspecies of Apis are available, 


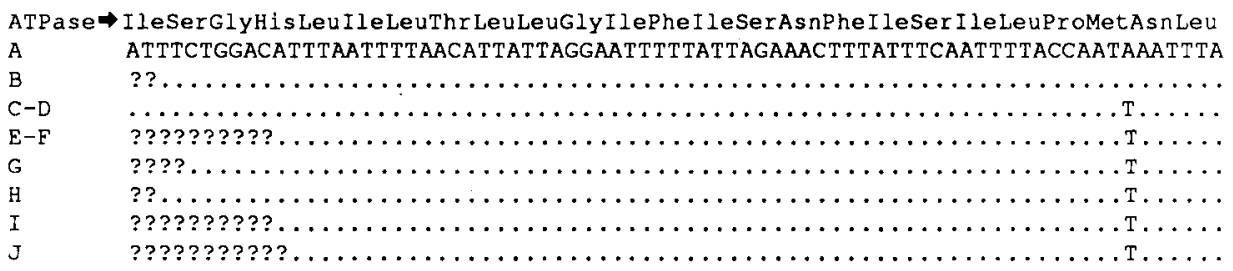

Met IleGlnAsnMet LeuLeuThr LeuGlu I lePheMet SerMet I leG InSerTyrValPheSer I le LeuLeuI leLeuTyr ATAAT TCAAAATATACTTTTAACT TAGAAATTTTATATCAATAATTCAAAGATATGTATTTTCAATTCTTTTAATTTATAT
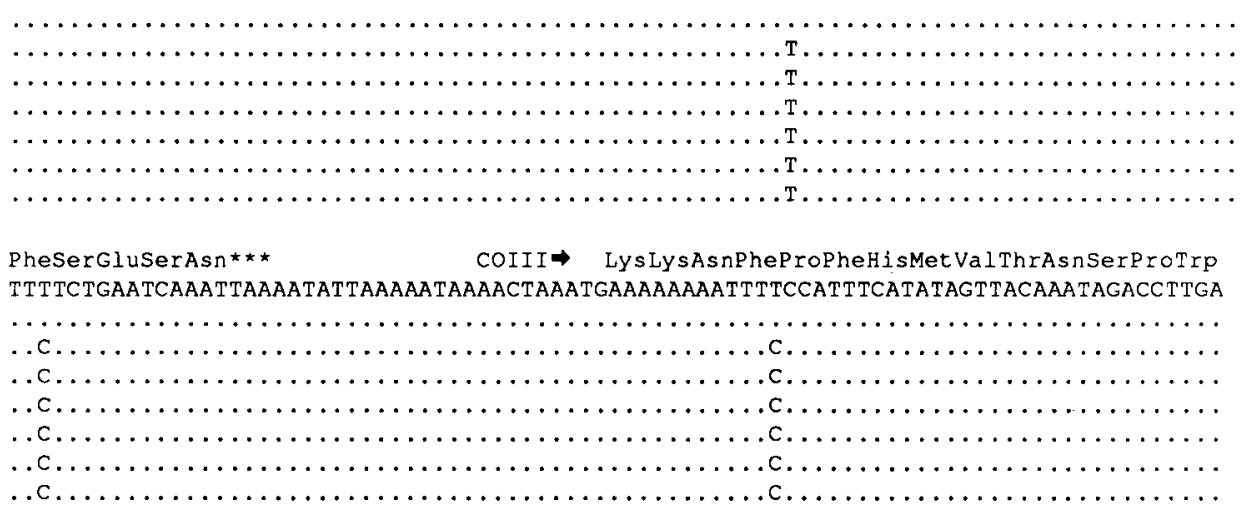

ProIleI leLeuSerPheSerPheMet AsnThr Leu leSerThrIleI leTrpIleTyrSerSerIleserMetpheMetIle (Val)

CCAATTATTTTATCATTTAGATT TATAAATACTCTCATTAGAACAATTATTTGAATTTATAGATCAATCTCAATATTTATAATT

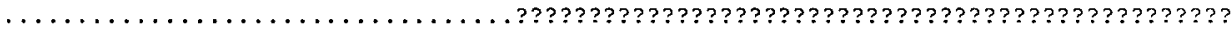

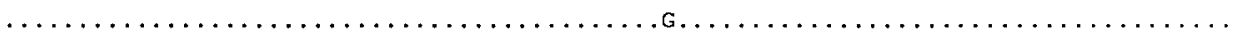

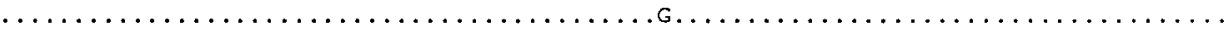

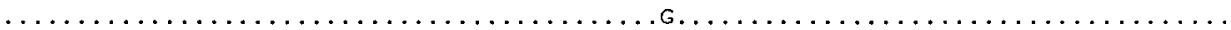

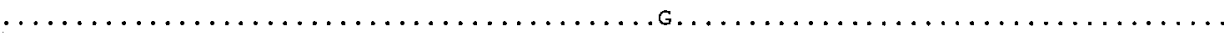

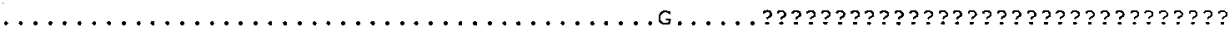

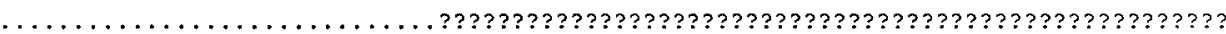

LeUAs nPheI leAsnSer I leLeuI leMetMet Leu ... TTTAATTTATTAATTCAATTTAATTATAATATTAT

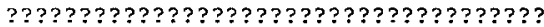

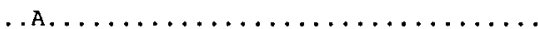

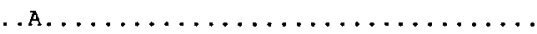

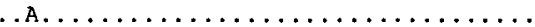

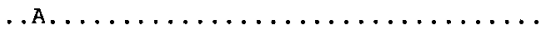

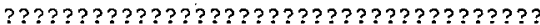

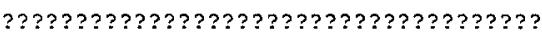

Fig 1. The nucleotide sequences obtained rom the ATPase 6, intergenic and COIII region. 363 bases were sequenced for $A$. The amino acids correspond to the codon directly below in $A$. The amino acid resulting from the base substitution in $C-J$ is in brackets. Dots represent bases which are the same as in A (A was taken from a commercial colony in Richmond, NSW. B was from a feral colony located $300 \mathrm{~km}$ north of Perth. J was from a second feral colony located $300 \mathrm{~km}$ north of Perth. C-J were obtained from commercial hives of Italian and Caucasian origin). 
it is safe to assume that the rate of evolution is $>2 \%$ sequence divergence per million years, as Apis mtDNA evolves more rapidly than those reported for other insects (Crozier et al, 1989). Considering European distribution patterns, Apis has existed there for 50000 years at most (Ruttner, 1988). Therefore the time of divergence must have occurred well before such strains colonized Europe. Sequence data from the cytochrome $b$ gene (SK, unpublished observations) supports the value obtained from the region reported here.

It is unlikely that these alleles arose in Australia after the bees were introduced, as this implies an incredible rate of evolution. However, it is a possibility that bees from another subspecies were sequenced, such as $A m$ mellifera which was introduced to Tasmania. This is less likely than our explanation, as the bees donated were identified by expert beekeepers as either A m caucasica or $A$ m ligustica.

\section{ACKNOWLEDGMENTS}

We thank the University of Western Sydney, the Department of Agriculture (Western Australia) and participating commercial beekeepers (Crestline Apiaries, T Brown and G Wheen) for donating the bees needed, and the Australian Research Council and the Honey Research Council for grant support to RHC.

Résumé - Deux allèles mitochondriaux anciens chez les abeilles australiennes. Les études biométriques et les premières études de l'ADN impliquaient seulement les sites où des enzymes spécifiques clivent I'ADN. Une telle information permet la caractérisation des races d'abeilles mais n'a généralement pas la puissance nécessaire pour délimiter des lignages à l'intérieur des races. Le séquençage de l'ADN augmente considérable- ment le volume d'information et améliore ainsi notre capacité à distinguer des souches les unes des autres. Nous rapportons dans cet article une méthode de séquençage de l'ADN mitochondrial (basée sur la technique de Polymerase chain reaction (PCR)). Nous pouvons séquencer de I'ADN d'abeilles isolées, ce qui nous permet le développement de tests de diagnose rapide de souches particulières. Les séquences obtenues dans cette étude, en utilisant l'ATPase 6 et les gènes mitochondriaux COlll ont permis de caractériser des souches australiennes sauvages et commerciales. L'ADN total a été extrait par l'une des 2 méthodes suivantes:

- à partir d'abeilles uniques, en utilisant la méthode de Crozier et al (1991);

- en utilisant la méthode de Crozier et al (1989) à partir d'ADN total, enrichi avec de I'ADN mitochondrial provenant du thorax de 12 abeilles de chaque ruche, homogénéisé doucement dans $18 \mathrm{ml}$ de solution d'homogénéisation. Le séquençage direct de produit de PCR simple brin fut obtenu en modifiant le protocole de Kessing et al (1989) et analysé en utilisant le Nucleic Acids Analysis System Package (Genesearch, Broadbeach, Queensland) qui fonctionne sur ordinateur Apple II. La divergence entre allèles (d) fut estimée par la méthode de Kimura (1980). La divergence moyenne entre les 2 allèles détectés, déterminée d'après les séquences de la figure 1 , est de $0,0167 \pm 0,0007$ (intervalle de confiance de $95 \%$ ). Bien que l'on ne dispose pas d'estimations de temps de divergence pour les sous-espèces d'Apis, on peut affirmer raisonnablement que le taux d'évolution est $>2 \%$ de divergence de séquence par million d'années, étant donné que I'ADN mitochondrial d'Apis évolue plus rapidement que celui des autres insectes. Si l'on considère les schémas de sa distribution en Europe, Apis existe depuis, au plus, 50000 ans. Par conséquent, le mo- 
ment de la divergence a dû se situer bien avant que les souches ne colonisent l'Europe. Les séquences obtenues par l'analyse du gène du cytochrome $b$ confirment nos résultats. II est peu probable que ces allèles soient apparus après l'introduction des abeilles en Australie, car cela impliquerait un taux d'évolution trop important. Cependant, il est possible que nous ayions séquencé l'ADN d'abeilles d'une autre sous-espèce, comme $A m$ mellifera, qui a été introduite en Tasmanie. Cela est moins probable que notre explication car les abeilles ont été identifiées par des experts comme étant $A m$ caucasica ou $A m$ ligustica.

\section{AND mitochondrial / variation génétique / Apis mellifera / évolution / Australie}

\section{Zusammenfassung - Zwei alte mito-} chondriale Allele bei australischen Honigbienen. Biometrische und frühere DNA-Untersuchungen betrafen nur die Stellen, wo spezifische Enzyme die DNA spalten. Solche Informationen gestatten zwar die Charakterisierung von Rassen der Honigbiene, aber ihnen fehlt gewöhnlich die Aussagekraft, um Abstammungslinien innerhalb der Rassen zu bestimmen. Die Sequenzierung von DNA vermehrt den Umfang der information beträchtlich und verbessert damit unsere Fähigkeit zur Unterscheidung von Stämmen.

Wir berichten hier über eine Methode der Sequenzierung (Spaltung in Einheiten) von mitochondrialer DNA (beruhend auf der polymerase-Kettenraktion, PCR). Wir sind in der Lage, die DNA einzelner Bienen zu sequenzieren und damit schnelle Diagnosetests für spezielle Stämme zu entwikkeln. Die Sequenzen für die mitochondrialen Gene von ATPase 6 und COIII wurden in dieser Studie benutzt, um sowohl Stämme von australischen Wildvöl- kern wie von kommerziellen Ständen zu charakterisieren.

Die gesamte DNA, angereichert mit mitochondrialer DNA (Crozier et al, 1989) wurde aus dem Thorax von 12 Bienen jeden Volkes extrahiert und vorsichtig in $18 \mathrm{ml}$ einer Homogenisierungslösung homogenisiert. Außerdem wurde die gesamte DNA des Genoms einzelner Bienen nach der modifizierten CTAB-methode (Boyle et al, 1989) isoliert. Direkte Sequenzierung von einsträngigen PCR-Produkten wurden durch Modifizierung des Protokolls von Kessing et al (1989) erreicht. Die Analyse wurde nach dem Nucleic Acids Analysis System Package (Genesearch, Broadbeach, Queensland) auf einem Apple II Computer durchgeführt. Die Distanzen (d) wurden nach der Methode von Kimura (1980) geschätzt. Die Zeitspanne seit der Divergenz $(t)$ wurde nach der Formel $t=$ $d / r$ geschätzt, wobei $r$ die Divergenzrate zwischen den beiden Sequenzen darstellt (Nei, 1987).

Nach den Sequenzdaten von Abbildung 1 beträgt die mittlere Divergenz (mit 95\% Vertrauensgrenzen) zwischen den beiden entdeckten Allelen $0.0167 \pm 7 \times 10^{-4}$. Obwohl es für die Subspezies von Apis keine Divergenzdaten gibt, kann man mit einiger Sicherheit annehmen, daß die Evolutionsrate $>2 \%$ Sequenzdivergenz pro Million Jahre beträgt, da sich die Apis-mtDNA schneller entwickelt als von anderen Insekten berichtet wird (Crozier et al, 1989). Nach dem europäischen Verbreitungsmuster hat Apis dort seit höchstens 50000 Jahren existiert (Ruttner, 1988). Deshalb muß der Zeitpunkt der Divergenz vor Eindringen dieser Stämme nach Europa gelegen sein. Die Sequenzdaten des Cytochrom b-Gens (SK, nicht publiziert) unterstützen die Werte aus der hier angeführten Region. Als alternative Erklärung könnte eine andere Subspezies (als $A m$ ligustica und $A m$ caucasica) nach Austra- 
lien eingeführt worden sein, doch gibt es darüber keine Angaben.

mitochondriale DNA / genetische Variation / Apis mellifera / Evolution / Australien

\section{REFERENCES}

Baba-Aissa F, Solignac M (1984) La plupart des populations de Drosophila simulans ont probablement pour ancêtre une femelle unique dans un passé récent. Acad Sci (Paris) 299, 289-292

Crozier RH (1980) Genetical structure of social insect populations. In: Evolution of Social Behaviour: Hypotheses and Empirical Tests (MarkJ $H$, ed) Verlag Chemie, Weinheim, 129-146

Crozier RH, Crozier YC, Mackinlay AG (1989) The CO-I and CO-Il region of honeybee mitochondrial DNA: evidence for variation in insect mitochondrial evolutionary rates. Mol Biol Evol 6, 399-411

Crozier YC, Koulianos S, Crozier RH (1991) An improved test for Africanized honeybee mitochondrial DNA. Experientia 47, 968-969

DeSalle R, Giddings LV, Kaneshiro KY (1986) Mitochondrial DNA variability in natural populations of Hawaiian Drosophila. II. Genetic and phylogenetic relationships of natural populations of $D$ silvestris and $D$ heteroneura. Heredity 56, 87-96
Salle R, Freedman T, Prager EM, Wilson AC (1987) Tempo and mode of sequence evolution in mitochondrial DNA of Hawaiian Drosophila. J Mol Evol 26, 157-164

Kessing B, Croom H, Martin A, Mclntosh C, McMillan WO, Palumbi S (1989) The Simple Fool's Guide to PCR (Version 1.0). University of Hawaii, Honolulu

Kimura M (1980) A simple method for estimating evolutionary rates of base substitutions through comparative studies of nucleotide sequences. J Mol Evol 16, 111-120

Latorre A, Barrio E, Moya A, Ayala FJ (1988) Mitochondrial DNA evolution in Drosophila obscura group. Mol Biol Evol 5, 717-728

Nei M (1987) Molecular Evolutionary Genetics. Columbia University Press, New York

Ruttner F (1988) Biogeography and Taxonomy of Honeybees. Springer-Verlag, Berlin

Satta Y, Toyohara N, Ohtaka C, Tatsuno Y, Watanabe T, Matsuura ET, Chigusa SI, Takahata $N$ (1988) Dubious maternal inheritance of mitochondrial DNA in $D$ simulans and evolution of $D$ mauritiana. Genet Res (Camb) 52, 1-6

Smith DR (1991) African bees in the Americas: insights from biogeography and genetics. Trends Ecol Evol 6, 17-21

Smith DR, Brown WM (1987) Polymorphisms in mitochondrial DNA of European and Africanized honeybees (Apis mellifera). Experientia $44,257-260$ 